\title{
The Ross procedure is an excellent operation in non-repairable aortic regurgitation: insights and techniques
}

\author{
Amine Mazine ${ }^{1}$, Ismail El-Hamamsy ${ }^{2}$ \\ ${ }^{1}$ Division of Cardiac Surgery, Department of Surgery, University of Toronto, Toronto, Ontario, Canada; ${ }^{2}$ Department of Cardiovascular Surgery, \\ Mount Sinai Hospital, Icahn School of Medicine at Mount Sinai, New York, New York, USA \\ Correspondence to: Ismail El-Hamamsy, MD, PhD. Department of Cardiovascular Surgery, Mount Sinai Hospital, 1190, Fifth Avenue, New York, New \\ York, 10029, USA. Email: ismail.el-hamamsy@mountsinai.org.
}

\begin{abstract}
The Ross procedure is the best operation to treat aortic stenosis (AS) in young and middle-aged adults. However, its role in non-repairable aortic regurgitation (AR) remains debated since many historical series have reported an increased risk of pulmonary autograft dilatation and subsequent need for reintervention in these patients. Some have attributed these findings to an unrecognized and poorly characterized inherited genetic defect that prevents adaptive remodelling of the pulmonary autograft. Herein, we review the contemporary evidence surrounding the use of the Ross procedure in young adults with AR and put forth the argument that with proper technical refinements, the Ross procedure may still be the best operation to treat these patients. We believe that by tailoring the operation to the patient's anatomy and ensuring strict postoperative blood pressure control, one can achieve excellent results with the Ross procedure, including in this challenging patient population.
\end{abstract}

Keywords: Ross procedure; aortic regurgitation (AR); pulmonary autograft

Submitted Jan 21, 2021. Accepted for publication Jun 10, 2021.

doi: 10.21037/acs-2021-rp-25

View this article at: https://dx.doi.org/10.21037/acs-2021-rp-25

\section{Introduction}

Aortic valve repair and aortic valve-sparing operations are the procedures of choice in young and middle-aged adults with aortic regurgitation (AR) $(1,2)$. When performed in expert centers, these operations result in good durability and freedom from valve-related complications, which translate into excellent long-term survival $(3,4)$. When the aortic valve cannot be repaired or spared, replacement options include prosthetic aortic valve replacement (AVR) or pulmonary autograft replacement (i.e., the Ross procedure). Many large studies have consistently demonstrated a survival disadvantage in non-elderly patients who undergo prosthetic AVR compared with the age- and sex-matched general population $(5,6)$. Importantly, the most significant excess mortality is observed in the youngest patients, who have prolonged cumulative lifelong exposure to valverelated complications (7-9). In addition, a number of studies have suggested that bioprosthetic AVR is associated with worse survival than mechanical AVR in young and middle-aged adults $(10,11)$. Despite this, there has been a significant increase in the use of bioprostheses for AVR over the last two decades in this age group (12). This trend has been fueled by enthusiasm for valve-in-valve transcatheter aortic valve implantation (TAVI) for the management of bioprosthetic valve failure. However, valve-in-valve TAVI has not been evaluated in young patients, and there are many reasons to be cautious with this strategy (13).

Against this backdrop, and in light of the suboptimal outcomes of prosthetic AVR in young and middleaged adults, there has been renewed interest in the Ross procedure. First described by Donald Ross in 1967 (14), this procedure is the only replacement operation that allows for long-term viability of the aortic root. Due to its biological and hemodynamic properties, the Ross procedure results in low rates of valve-related complications, excellent quality of life and long-term survival equivalent to that of the ageand sex-matched general population, making it an appealing 
option for young and middle-aged adults requiring AVR. In addition, several recent publications from expert centers have shown that the Ross procedure is associated with better long-term outcomes than conventional prosthetic AVR alternatives, be they biological or mechanical, in appropriately selected patients (15-18). In light of this increasing body of evidence, many experts now view the Ross procedure as the best operation to treat aortic stenosis (AS) in young adults (19). However, its use in patients presenting with AR remains debated (20). This is due to the increased risk of pulmonary autograft dilatation and subsequent need for reintervention in these patients $(21,22)$. While it remains uncertain why certain patients develop autograft dilatation and others do not, several studies have consistently drawn an association between this complication and the presence of pre-operative AR, especially when associated with a dilated aortic annulus $(20,23)$. As a result, the current Society of Thoracic Surgeons guidelines allocate the Ross procedure a Class III recommendation, stating that it should not be performed in patients with bicuspid aortic valve (BAV) and $\mathrm{AR}$ (24).

This creates a conundrum, as patients with AR are typically younger than those with AS and hence stand to benefit the most from the long-term advantages of a living aortic valve substitute. Herein, we review the contemporary evidence surrounding the use of the Ross procedure in young adults with AR and put forth the argument that with proper technical refinements, the Ross procedure may still be the best operation to treat these patients.

\section{Impact of pre-operative AR on pulmonary autograft durability}

Patients with AR tend to undergo surgery at a younger age. They are also more likely to present with congenital aortic valve anomalies (i.e., bicuspid, unicuspid or quadricuspid aortic valves), dilated aortic annuli, ascending aortic aneurysm and size mismatch between the pulmonary and aortic roots. As a result of these factors, various clinical studies have shown that patients undergoing the Ross procedure for AR are at greater risk of autograft dilatation and reoperation than those with AS (Table 1) (20-22,25,27-30).

David et al. reported on a cohort of 212 patients (mean age $34 \pm 9$ years; $66 \%$ male) who underwent the Ross procedure between 1990 and 2004 (20,29,30). Congenital aortic valve disease, predominantly $\mathrm{BAV}$, was present in $82 \%$ of cases. The indication for surgery was AS in $50 \%$ of patients, AR in $36 \%$ and mixed disease in $13 \%$. An aortic annulus $>27 \mathrm{~mm}$ was seen in $57 \%$ of patients. Surgical reduction of the aortic annulus (via sub-commissural plication of the non-coronary sinus and partial annuloplasty using a Dacron ring) or sinotubular junction (via plication of the ascending aorta) was performed in $58 \%$ of cases. The pulmonary autograft was secured in the aortic position using the subcoronary implantation or aortic root inclusion techniques in 104 patients and as a free-standing neo-aortic root in 108 patients. This cohort was followed prospectively. At a mean follow-up of $10.1 \pm 4.2$ years, 13 patients required reoperation on the pulmonary autograft, translating into a freedom from autograft reoperation of $92.1 \% \pm 2.3 \%$ at 15 years $(97 \%$ in patients with AS versus $84 \%$ in patients with AR) (20). Pre-operative AR was the only independent predictor of reoperation (hazard ratio, 5.4; $95 \%$ confidence interval, 1.2-24.0).

David et al. subsequently published two updates on this cohort. The first study reported outcomes at a median follow-up of 13.8 years (29). Two additional patients required pulmonary autograft reoperation, for a total of 15 . Once again, the authors identified pre-operative AR, along with male sex and an aortic annulus diameter $\geq 15 \mathrm{~mm} / \mathrm{m}^{2}$, as a risk factor for pulmonary autograft reoperation. Pre-operative AR and aortic annular diameter were also associated with an increased risk of late AR. Most recently, the authors reported the long-term outcomes of this cohort, at a median follow-up of 18.0 years (30). There were 23 autograft reoperations, yielding a freedom from autograft reoperation of $88.5 \%$ at 20 years. Older age at surgery and larger pre-operative aortic annulus diameter were associated with increased risk of pulmonary autograft reoperation on multivariable analysis. Interestingly, preoperative AR was no longer an independent predictor of autograft reoperation. It remained, however, associated with the development of postoperative AR. This latest report also provided granular information about the patients who underwent autograft reintervention. Of these, 16 presented with pre-operative AR, 5 with AS and 2 with mixed lesions. The indication for reoperation was autograft insufficiency in all but five patients (three patients in the "AR" group who developed a false aneurysm, an aortic root aneurysm and an ascending aortic aneurysm, respectively; and two patients in the "AS" group who developed a false aneurysm and an aortic root aneurysm, respectively). There was also a significant difference in the time to reoperation, with patients in the "AR" group undergoing reintervention at a median of 10.4 years, versus 13.0 years in the "mixed lesion" group and 19.3 years in the "AS" group. 


\begin{tabular}{|c|c|c|c|c|c|c|c|c|c|}
\hline Study & $\begin{array}{l}\text { \# of } \\
\text { patients }\end{array}$ & $\begin{array}{l}\text { Mean } \\
\text { age } \\
\text { (years) }\end{array}$ & $\begin{array}{l}\text { BAV/ } \\
\text { UAV/QAV } \\
(\%)\end{array}$ & $\begin{array}{l}\text { AS (\%)/AR (\%)/ } \\
\text { mixed AS-AR } \\
(\%)\end{array}$ & $\begin{array}{l}\text { Surgical } \\
\text { technique }\end{array}$ & $\begin{array}{l}\text { Annuloplasty } \\
(\%)\end{array}$ & Annuloplasty type & $\begin{array}{l}\text { Mean } \\
\text { follow-up } \\
\text { (years) }\end{array}$ & $\begin{array}{l}\text { Freedom from } \\
\text { autograft } \\
\text { reoperation }\end{array}$ \\
\hline $\begin{array}{l}\text { David et al. } \\
\text { [2010] (20) }\end{array}$ & 212 & $34 \pm 9$ & 82 & $50 / 36 / 13$ & $\begin{array}{l}\text { RR }(51 \%) \text {, } \\
\text { SC/inclusion } \\
(49 \%)\end{array}$ & 46 & $\begin{array}{l}\text { Subcommissural } \\
\text { plication + partial } \\
\text { Dacron strip }\end{array}$ & $10.1 \pm 4.2$ & $\begin{array}{l}\text { At } 15 \text { years: } \\
\text { AS } 97 \% \text {, } \\
\text { AR } 84 \%\end{array}$ \\
\hline $\begin{array}{l}\text { Weimar } \\
\text { et al. } \\
\text { [2014] (25) }\end{array}$ & 645 & $42 \pm 14$ & 58 & $32 / 29 / 33$ & $\begin{array}{l}\mathrm{RR}(98 \%), \\
\mathrm{SC}(2 \%)\end{array}$ & 63 & Dacron strip & $8.4 \pm 4.6$ & $\begin{array}{l}\text { At } 10 \text { years: } \\
\text { AS } 97 \%, \mathrm{Al} \\
90 \%\end{array}$ \\
\hline $\begin{array}{l}\text { Skillington } \\
\text { et al. } \\
\text { [2015] (23) }\end{array}$ & 322 & $\begin{array}{l}40 \\
\text { (range } \\
15-63)\end{array}$ & 95 & $46 / 32 / 22$ & $\begin{array}{l}\text { Inclusion } \\
(100 \%)\end{array}$ & 62 & $\begin{array}{l}\text { Circumferential ring } \\
(5 \%), \text { partial ring } \\
(30 \%) \text {, partial ring } \\
+ \text { annular plication } \\
(25 \%) \text {, annular } \\
\text { plication }(2 \%)\end{array}$ & 9.8 & $\begin{array}{l}\text { At } 18 \text { years: } \\
96 \% \text { overall } \\
\text { AS: } n=1, \text { AR: } \\
n=9, \text { AS/AR: } \\
n=1\end{array}$ \\
\hline $\begin{array}{l}\text { Mastrobuoni } \\
\text { et al. } \\
\text { [2016] (26) }\end{array}$ & 306 & $42 \pm 10$ & 59 & $68 / 31 / 0$ & $\begin{array}{l}\mathrm{SC}(2 \%), \\
\mathrm{RR}(55 \%), \\
\text { inclusion } \\
(43 \%)\end{array}$ & $N / A$ & $\mathrm{~N} / \mathrm{A}$ & 10.6 & $\begin{array}{l}\text { At } 16 \text { years: } \\
\text { AS } 83 \% \text {, } \\
\text { AR } 65 \%\end{array}$ \\
\hline $\begin{array}{l}\text { Charitos } \\
\text { et al. } \\
\text { [2012] (21) }\end{array}$ & 1760 & $44 \pm 12$ & 71 & $24 / 23 / 51$ & $\begin{array}{l}\text { SC }(44 \%) \text {, } \\
\operatorname{RR}(56 \%)\end{array}$ & 35 & $N / A$ & $7.1 \pm 4.6$ & $\begin{array}{l}\text { HR (AR vs. } \\
\text { AS): } 2.3(95 \% \\
\text { Cl: } 1.5-3.5) \\
P<0.001\end{array}$ \\
\hline $\begin{array}{l}\text { Da Costa } \\
\text { et al. } \\
{[2014](27)}\end{array}$ & 414 & $31 \pm 13$ & 50 & $29 / 39 / 31$ & $\begin{array}{l}\text { RR (86\%), } \\
\text { inclusion } \\
(14 \%)\end{array}$ & 7 & $\begin{array}{l}\text { External strip of } \\
\text { Dacron/pericardium }\end{array}$ & $8.2 \pm 5.2$ & $\begin{array}{l}\text { At } 15 \text { years: } \\
91 \% \text { overall }\end{array}$ \\
\hline $\begin{array}{l}\text { Martin et al. } \\
\text { [2017] (22) }\end{array}$ & 310 & $41 \pm 11$ & 78 & $73 / 19 / 7$ & $\begin{array}{l}\mathrm{RR}(84 \%) \text {, } \\
\text { inclusion } \\
(11 \%), \mathrm{SC} \\
(6 \%)\end{array}$ & 1 & N/A & $\begin{array}{l}15.1(\mathrm{IQR} \\
5.5-18.4)\end{array}$ & $\begin{array}{l}\text { HR (AR vs. } \\
\text { AS): } 2.7(95 \% \\
\text { Cl: } 1.4-5.1) \\
P=0.002\end{array}$ \\
\hline $\begin{array}{l}\text { Ryan et al. } \\
\text { [2011] (28) }\end{array}$ & 160 & $42 \pm 11$ & 87 & $42 / 58 / 0$ & $\mathrm{RR}$ & 38 & $\begin{array}{l}\text { Circumferential } \\
\text { suture annuloplasty }\end{array}$ & $\begin{array}{l}\text { AS } \\
4.5 \pm 2.9 \\
\text { AR } \\
6.0 \pm 3.2\end{array}$ & $\begin{array}{l}\text { At } 10 \text { years: } \\
\text { AS } 95 \% \pm 5 \% \text {, } \\
\text { AR } 67 \% \pm 9 \%\end{array}$ \\
\hline
\end{tabular}

AR, aortic regurgitation; AS, aortic stenosis; BAV, bicuspid aortic valve; HR, hazard ratio; IQR, interquartile range; QAV, quadricuspid aortic valve; RR, root replacement; SC, subcoronary; UAV, unicuspid aortic valve.

The association between pre-operative AR and reduced durability of the pulmonary autograft has also been reported by others. Ryan et al. reported on a cohort of 160 patients (mean age $42 \pm 11$ years; $73 \%$ male) who underwent a Ross procedure from 1994 to 2008 (28). Pre-operatively, 42\% of patients presented with AS and $58 \%$ with AR. A BAV was diagnosed in $91 \%$ of AS patients and $85 \%$ of AR patients. The Ross procedure was performed using the free-standing root replacement technique in all cases. An annuloplasty, consisting of a circumferential suture annuloplasty, was performed in $18 \%$ of patients in the AS group and $53 \%$ of patients in the AR group. At a mean follow-up of 5.4 years, a total of 15 patients had required autograft reoperation, 14 of whom had pre-operative AR. Univariable logistic regression analysis showed a 10.7 -fold increase in the risk of autograft reoperation in patients presenting with preoperative AR.

Charitos et al. examined the midterm outcomes of the Ross procedure in the multicenter German-Dutch Ross Registry (21). A total of 2023 patients (mean age 
$39 \pm 17$ years; $74 \%$ male) across 13 centers were included. The indication for surgery was AS in $23 \%$ of patients, $\mathrm{AR}$ in $23 \%$ and mixed lesion in $52 \%$. A congenital valve malformation was present in $71 \%$ of patients $(62 \% \mathrm{BAV}$, $9 \%$ other). Mean follow-up was $7.1 \pm 4.6$ years. Patients were stratified into three groups based on surgical technique: subcoronary implantation $(\mathrm{n}=771)$, root replacement without additional root reinforcement procedures $(n=346)$ and root replacement with root reinforcement $(\mathrm{n}=643)$. In the latter group, reinforcement interventions were performed either in the annulus only ( $\mathrm{n}=394)$, the sinotubular junction only $(n=35)$ or at both levels $(n=214)$. On multivariable analysis, the presence of pure AR pre-operatively (hazard ratio, $2.3 ; 95 \%$ confidence interval, $1.5-3.5$ ) and the use of the root replacement technique without root reinforcement (hazard ratio, 2.4; 95\% confidence interval, 1.4-4.1) were independent predictors of shorter time to reoperation. Thus, these data confirmed the notion that pre-operative $\mathrm{AR}$ is an independent risk factor for reoperation but suggested that the effect might be milder than previously reported and more pronounced in the root replacement technique without active reinforcement, suggesting that technical factors might be at play. Furthermore, the study also demonstrated that center volume had a significant influence on long-term outcomes, with low-volume centers showing higher rates of reoperation, further highlighting the potential impact of technical factors.

da Costa et al. examined outcomes of the Ross procedure in a cohort of 414 patients (mean age $31 \pm 13$ years; $75 \%$ male) (27). A bicuspid or unicuspid valve was present in $50 \%$. The indication for surgery was AS in $29 \%$, AR in $39 \%$ and mixed disease in $31 \%$. A root replacement was performed in 356 patients, while the inclusion technique was used in 58 patients. A pre-operative aortic annulus diameter $\geq 27 \mathrm{~mm}$ was seen in $26 \%$ of patients, yet only $7 \%$ underwent external annular reduction. In an effort to avoid prosthetic material, the authors never reinforced the distal suture line, even in the presence of ascending aorta dilatation. Mean follow-up was $8.2 \pm 5.2$ years. There were 22 reoperations on the pulmonary autograft, yielding a $91 \%$ freedom from autograft reoperation at 15 years. As in previous studies, univariable log-rank analysis revealed preoperative AR and an aortic annulus $\geq 27 \mathrm{~mm}$ as the most substantial risk factors for the development of more than mild AR or autograft dilation at late follow-up.

Weimar et al. reported on a cohort of 645 Ross procedure patients (mean age, $42 \pm 14$ years; $76 \%$ male), of which $32 \%$ presented with AS, 29\% with AR and 33\% with mixed disease (25). A BAV was diagnosed in $58 \%$ of patients. The root replacement technique was used in $98 \%$ of cases $35 \%$ without reinforcement and $63 \%$ with reinforcement using a Dacron strip). Mean follow-up was $8.4 \pm 4.6$ years. Freedom from reoperation on the autograft at 12 years was $92 \%$. Once again, pre-operative $\mathrm{AR}$ and an aortic annulus $\geq 26 \mathrm{~mm}$ were identified as predictors of autograft failure. Unlike in the German-Dutch Ross Registry study (21), the authors could not observe a significant difference in the need for reoperation between patients who underwent annular reinforcement and those who did not.

Martin et al. reported the long-term outcomes of 310 patients (mean age, 41 years; $60 \%$ male) who underwent the Ross procedure for AS (73\%), AR (19\%) and mixed disease (7\%) (22). A congenital valve anomaly was seen in $78 \%$ of patients. The mean aortic annular size in this cohort was $23 \pm 3 \mathrm{~mm}$. The authors reported that patients with an aortic annulus $>27 \mathrm{~mm}$ were frequently denied the Ross procedure. A root replacement technique was used in $84 \%$ of patients. The authors did not systematically stabilize the autograft, and consequently, rates of concomitant reduction annuloplasty (1\%) and ascending aortic replacement (13\%) were low. The median follow-up was 15.1 years. A total of 32 patients $(10.3 \%)$ required autograft-related reoperations at a median of 13.8 years, yielding a freedom from autograft reintervention of $96 \%$ at ten years and $76 \%$ at 20 years. Upon multivariable Cox regression analysis, independent risk factors for pulmonary autograft degeneration were pre-operative $\mathrm{AR}$ (hazard ratio: 2.7; $\mathrm{P}=0.002$ ), a large aortic annulus (hazard ratio: $1.1 ; \mathrm{P}=0.01$ ) and concomitant replacement of the ascending aorta (hazard ratio: $7.7 ; \mathrm{P}=0.0003)$.

Thus, a large number of studies examining outcomes of the Ross procedure in adults have consistently drawn an association between pre-operative AR and early autograft failure, a fortiori when aortic annular dilation is present. It should be noted, however, that in most of these studies, the root replacement technique was heavily favored, and in most cases, no effective systematic root stabilization strategies nor blood pressure control protocols were in place for patients with AR. In the following sections, we examine the potential causes of this association, and ask whether they can be addressed at the time of surgery and in the early postoperative period. Furthermore, since reoperation is only one of many important metrics to consider when evaluating the results of valve surgery in young patients, we examine whether preoperative AR has an impact on other critical outcomes such as survival and quality of life. 


\section{Mechanistic insights and technical considerations}

While risk factors for pulmonary autograft dilatation have been identified, the underlying pathophysiology remains incompletely understood. On the basis of the evidence summarized in the previous section, it has been proposed that patients with $\mathrm{AR}$ and a dilated aortic annulus may have a genetic abnormality of the pulmonary valve and artery wall that impairs adaptive remodelling of the autograft and predispose to early dilatation and failure. Indeed, the Ross procedure results in a significant increase in pressure on the pulmonary autograft after implantation in the aortic position, compared with its native position within the pulmonary circulation. The reason that a majority of patients do not develop aneurysmal dilatation is due to the autograft's ability to adapt and remodel in response to this drastic change in hemodynamic conditions. It has been suggested that patients with AR and a dilated aortic annulus may have an unrecognized inherited vascular anomaly that thwarts this process. Support for this hypothesis comes from the observation, in certain series, that surgical maneuvers aimed at preventing autograft dilatation do not appear effective in these patients. Indeed, early on in their experience with the Ross procedure, David et al. recognized that the pulmonary and aortic roots often had different dimensions in patients with $\mathrm{AR}$ and that this size mismatch was a cause of recurrent AR after the Ross procedure (31). In response, the authors began to systematically adjust the size of the aortic annulus prior to autograft implantation in patients who had $>2 \mathrm{~mm}$ mismatch. This was achieved by way of sub-commissural plication of the non-coronary sinus (at either one or both subcommissural spaces) and partial annuloplasty using a Dacron ring in selected patients. The diameter of the sinotubular junction of the neo-aortic root was also surgically adjusted to that of the pulmonary autograft via plication of the ascending aorta. These maneuvers, though useful in mitigating early postoperative dilatation and AR, did not prevent late autograft failure (20), leading the authors to conclude that a dilated aortic annulus is a marker of premature autograft degeneration that cannot be addressed surgically.

Several observations argue against this "genetic" hypothesis. First, recent cardiac magnetic resonance imaging studies have shown that when using a patientspecific tailored approach (see below), there is no early difference in autograft dimension, stiffness or geometry at one year between patients undergoing the Ross procedure for AS versus AR (32). This suggests that under the right conditions, the pulmonary autograft of patients with $\mathrm{AR}$ is capable of the same adaptive remodelling as that of patients with AS. Second, studies have shown that in patients who require reoperation for autograft dilatation, the majority of the dilatation has already occurred at the time of discharge from the hospital (33), suggesting that technical issues may be at play. Third, none of the studies mentioned in the previous section included strict postoperative blood pressure control. Fourth, subcommissural suture plication, which has proven to be ineffective in preventing late autograft failure, has also proven to be ineffective in the context of aortic valve repair (34). This is due to the fact that in AR, the main issue is dilatation at the level of the muscular rather than the fibrous portion of the annulus-an issue that is not addressed with subcommissural sutures. In contrast to subcommissural annuloplasty, other approaches have demonstrated more promising results. Broadly speaking, these approaches provide external support to the autograft and ensure strict blood pressure control during the early adaptive phase. These strategies are reviewed in detail in the next section.

\section{External support of the pulmonary autograft}

Over the last decade, a number of technical modifications have been proposed to provide external support to the autograft and mitigate the risk of dilatation and failure. These include autologous support using the patient's own aortic root-the inclusion technique-(Figure 1A) (23), reinforcement of the pulmonary autograft with a prosthetic Dacron tube (Figure 1B) (35) and a "tailored surgical" approach (Figure 1C) (36,37). Each of these approaches has advantages and limitations.

\section{Autologous support (inclusion technique)}

In an effort to prevent autograft dilatation while avoiding the use of prosthetic material, several groups have proposed using autologous tissue to provide external support to the pulmonary autograft. The two tissues used to this end are pericardium and the native aorta itself. While they might still somewhat limit the distensibility of the neo-aortic root, these tissues are thought to provide better mechanical properties than Dacron.

The largest experience with autologous support of the pulmonary autograft root using the patient's own aorta- 
A

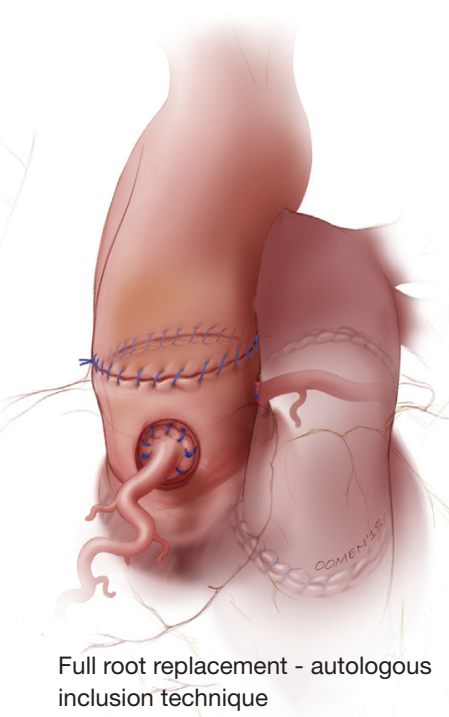

B

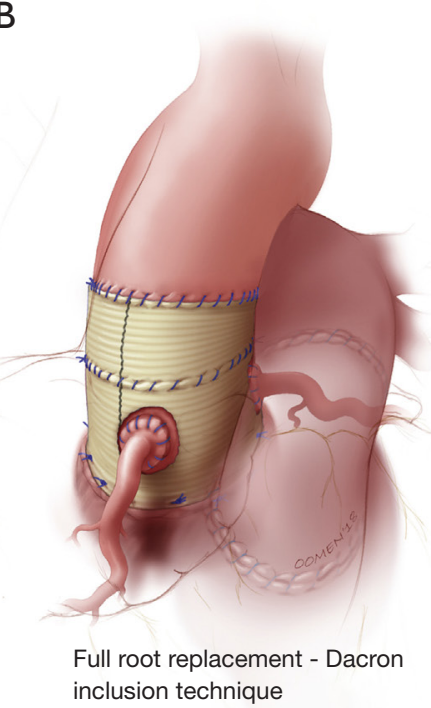

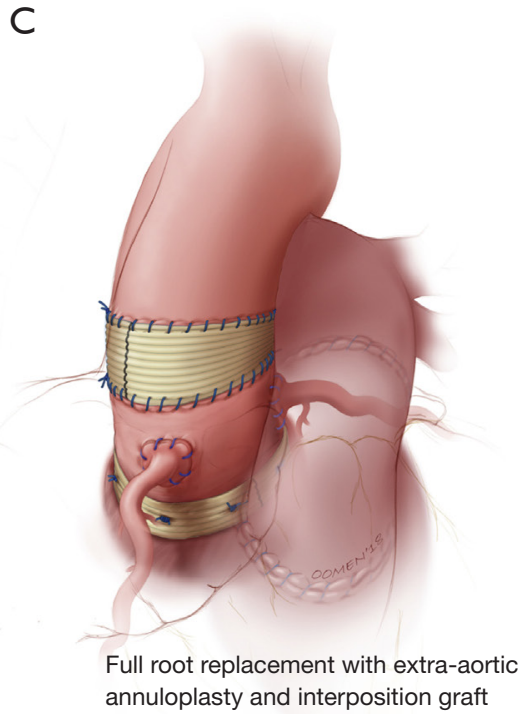

Figure 1 Technical modifications of the Ross procedure aimed at preventing late autograft dilatation and insufficiency. (A) Autologous inclusion technique; (B) Dacron inclusion technique; (C) tailored surgical approach.

the inclusion technique-(Figure 1A) comes from the Melbourne group, who reported long-term outcomes of this technique in 322 consecutive patients (23). Prior to implanting the pulmonary autograft, the native aorta and aortic root remnants were tailored to achieve specific sinotubular junction and aortic annulus measurements for male and female patients (24-26 and 22-24 mm, respectively). The long-term results of this strategy are impressive, with stable neo-aortic dimensions up to 15 years after surgery. Thus far, only $1.5 \%$ of all patients have developed a maximum aortic root size in excess of $40 \mathrm{~mm}$ in diameter, and none have exceeded $43 \mathrm{~mm}$. Consistent with previous studies, patients presenting with pre-operative $\mathrm{AR}$ and those with a large aortic annulus were at higher risk of developing larger neo-aortic root diameters at follow-up. These patients were also more likely to undergo reoperation. Nonetheless, overall freedom from autograft reoperation at 18 years was $96 \%$, and none of the reoperations were prompted by autograft dilatation (23).

In a sub-analysis of this cohort focusing on 129 patients who presented with BAV and pure AR, Poh et al. reported a total of 11 aortic reoperations (nine for recurrent $\mathrm{AR}$ and two for endocarditis), yielding an overall freedom from reoperation of $89 \%$ at 10 years, and $85 \%$ at 20 years (38). Of note, autograft failure in this cohort tended to occur early (i.e., within the first five years of follow-up). There was also a large era effect, with $45 \%$ of reoperations occurring in the first $25 \%$ of patients, prior to the maturation of the authors' surgical strategies. In addition to excellent autograft durability in this cohort of patients at high risk of autograft dilatation, late survival was also remarkable, with $96 \%$ freedom from all-cause mortality at 20 years.

Currently, these outstanding results represent the best available long-term outcomes of the Ross procedure in patients presenting with $\mathrm{AR}$, suggesting that when feasible, the Melbourne approach represents an excellent solution for addressing the issue of pulmonary autograft dilatation and failure in this group of patients. Nonetheless, a few crucial details ought to be considered when using this surgical strategy. Notably, the technique is not well suited for patients with unicuspid or Sievers type 0 bicuspid valves $\left(180^{\circ}\right.$ commissures), especially when there is a large discrepancy between the size of the aortic root and pulmonary autograft. Furthermore, the fact that the native aorta is always remodelled to the same dimensions according to the sex of the patient raises concerns about potential distortion in pulmonary autografts of different diameters.

The experience with pericardium wrapping is limited. Pacifico et al. reported their experience with 25 patients in whom the autograft was wrapped in pericardium (autologous pericardium in 12 patients, bovine pericardium in 13) (39). Early outcomes were favorable, demonstrating good valve competency with this technique, but long-term results have not been published. 


\section{External support with a Dacron tube}

In an effort to prevent autograft dilatation, several groups have proposed encasing the pulmonary autograft within a Dacron tube prior to implantation (Figure 1B) (35,40-43). Both straight grafts and Valsalva grafts (Terumo Vascutek, Renfrewshire, Scotland, UK) have been used to this end. This technique has shown good early results, with stable autograft annulus and neo-sinus diameters up to five years $(35,40-43)$. From our perspective, the main limitation of this approach is that it alters the shape of the autograft root, especially when using straight Dacron grafts, and impairs its natural dynamism. This could have negative repercussions on the instantaneous movements of the autograft cusps, on coronary flow reserve, and on left ventricular impedance, thereby potentially negating some of the main advantages of the Ross operation. Furthermore, the absence of mechanotransduction leads to extracellular matrix and smooth muscle cell disarray, which results in the autograft losing its elastic properties (44). These considerations are, for the time being, mostly theoretical, as no study has specifically examined this question in the context of the wrapped autograft. However, hemodynamic studies after the use of remodelling and reimplantation valve-sparing techniques lend support to these concerns $(45,46)$. The use of a Valsalva graft, which allows for sinus wall expansion, could potentially mitigate some of these phenomena.

Beyond these concerns, this approach also has a number of technical pitfalls. Insertion of the pulmonary autograft within a Dacron graft can cause distortion of its natural geometry, potentially leading to early AR. Furthermore, because the geometric height of the pulmonary cusps is longer than that of aortic cusps, insufficient height of the commissures within the Dacron graft can lead to leaflet prolapse and early autograft failure (43). Another pitfall is the potential for the coronary arteries to be distorted or kinked by the Dacron graft. It is critical to ensure that coronary anastomoses include both the autograft wall and the Dacron graft at the time of coronary reimplantation to avoid kinking the coronary artery. Another concern is the potential for blood to accumulate in the free space between the autograft wall and the Dacron graft, forming a hematoma that may compress the neo-aortic root or create a nidus for infection. Dacron itself, as a synthetic material, raises some concerns as it has been associated with increased inflammatory reaction around the pulmonary autograft, which might lead to early dysfunction and limit the longterm benefits of the Ross operation (47). The use of alternative synthetic materials, such as GoreTex (W.L. Gore \& Associates Inc., Flagstaff, AZ, USA), has been proposed, but long-term results are lacking (48).

In light of the aforementioned limitations, we do not currently advocate the systematic use of this technique. Long-term results of this approach, when they become available, may modify this stance. Nonetheless, we see value in this approach as it may open the possibility of considering the Ross procedure in patients previously deemed to have absolute contra-indications, such as young patients with connective tissue disorders and a non-sparable valve (49).

\section{Tailored surgical approach}

Patients presenting with $\mathrm{AR}$ and a dilated aortic annulus are at increased risk of autograft dilatation and failure. As previously described, several strategies using external support have proven effective in mitigating the risk of late autograft dilatation. However, these strategies may restrict the mobility of the pulmonary autograft and thereby limit some of the expected benefits of the Ross procedure. In an effort to minimize the risk of autograft dilatation while providing excellent hemodynamics and unrestricted autograft mobility, we advocate an approach whereby surgical and postoperative management is tailored to each individual patient. This approach focuses on known risk factors for autograft dilatation and targets them according to the patient's individual anatomy and characteristics. The aim is to stabilize or support the different components of the neo-aortic root to prevent dilatation at all levels: annulus, sinuses of Valsalva and sinotubular junction. Another aim of this approach is to minimize uncontrolled hypertension, a well-established risk factor for early autograft dilatation and failure, which is especially pronounced in patients with preoperative AR.

This tailored surgical approach (Figure 1C) has been described in detail elsewhere $(36,37)$. In summary, the autograft root is oriented so that the thinner, left-facing sinus sits in the left coronary sinus. Prior to implantation, we trim the autograft so that the least possible amount of infundibular muscle is left. The autograft is placed in the left ventricular outflow tract (subannular implantation) so that the native aortic annulus may provide annular support. In patients presenting with $\mathrm{AR}$, we systematically perform an extra-aortic annuloplasty using a complete circular Dacron ring to stabilize the aortic annulus further (50). We believe this approach to be more effective in preventing late increases in annular diameters compared with suture 


\begin{tabular}{|c|c|}
\hline Potential causes & Mitigating measures \\
\hline $\begin{array}{l}\text { Aortic annular dilatation } \\
\text { Aortic vs. pulmonary annular size mismatch } \\
\text { Inadequate annular reduction technique }\end{array}$ & $\begin{array}{l}\text { External circumferential ring annuloplasty } \\
\text { Loose autologous jacket }\end{array}$ \\
\hline Dilatation of autograft infundibular muscle & $\begin{array}{l}\text { Autograft infundibular muscle trimming } \\
\text { Subannular implantation }\end{array}$ \\
\hline Autograft distortion at implantation & Ensure commissural symmetry \\
\hline Sinotubular junction dilatation & $\begin{array}{l}\text { Autograft trimming } \\
\text { Proactive management of the mildly dilated ascending aorta (>36 mm) }\end{array}$ \\
\hline Uncontrolled hypertension & Strict blood pressure control \\
\hline $\begin{array}{l}\text { Unrecognized familial aortopathy/connective tissue } \\
\text { disorder }\end{array}$ & Careful screening \\
\hline
\end{tabular}

annuloplasty or partial rings. To provide further support, we use the native non-coronary sinus and left-right commissure as a loose external jacket. In addition, the pulmonary artery is trimmed immediately above the commissure to minimize the amount of pulmonary artery wall that will be exposed to systemic pressures. In patients with an ascending aortic diameter $>36 \mathrm{~mm}$ or a size mismatch of $>3-4 \mathrm{~mm}$ between the ascending aorta and autograft sinotubular junction at the time of surgery, we advocate proactive management of the ascending aorta, as dilatation of the sinotubular junction is a known mechanism of autograft failure. To mitigate this risk, we interpose a short Dacron graft between the autograft and the ascending aorta, which stabilizes the sinotubular junction (37). When employing this strategy, it is vital to keep the Dacron interposition graft as short as necessary, as we have observed that replacement of the ascending aorta with a Dacron graft, while stabilizing the sinotubular junction, results in a significant increase in autograft root stiffness (32), which may limit some of the benefits of the operation and lead to reduced autograft durability (22).

In addition to the aforementioned technical details, we have implemented a rigorous patient-centered remote blood pressure monitoring protocol, aiming for systolic blood pressure $\leq 110 \mathrm{mmHg}$ for the first 12 months after surgery. We believe this is critically important to allow the autograft wall to adapt to its new hemodynamic environment and avoid dilatation in this early adaptive phase. In our experience, over half of the patients with adequate blood pressure control at discharge required additional adjustments of antihypertensive medication dosages, highlighting the importance of continuous patient monitoring beyond the hospital stay.
These medication adjustments were most common in the first month after surgery and, notably, more frequent in patients with AR, compared to those with AS. Obviously, this approach relies heavily on patient cooperation, and adequate blood pressure control might be difficult to achieve in noncompliant patients.

Since 2011, we have performed $>500$ Ross procedures using this approach, with excellent mid-term results and no sign of autograft dilatation. In a recent analysis, no differences in autograft root dimensions were observed between patients with pre-operative AR versus AS up to seven years after surgery (36). Continued follow-up is warranted to confirm the long-term stability of autograft dimensions and determine the viability of this approach. In particular, it will be interesting to determine the impact of this tailored surgical approach on the incidence of primary autograft leaflet failure, such as what has been observed in other series (20).

\section{Looking at the big picture}

As summarized in this article, several studies have consistently identified pre-operative AR and aortic annular dilatation as predictors of autograft failure. As such, patients presenting with these features represent a suboptimal anatomic substrate for the Ross operation. Nonetheless, when considering this evidence and ascertaining the role of the Ross procedure in this patient group, a few salient features should be kept in mind.

First, the Ross procedure represents an "evolutionary tale", meaning that although the operation was introduced more than half a century ago, it has continued to evolve through 


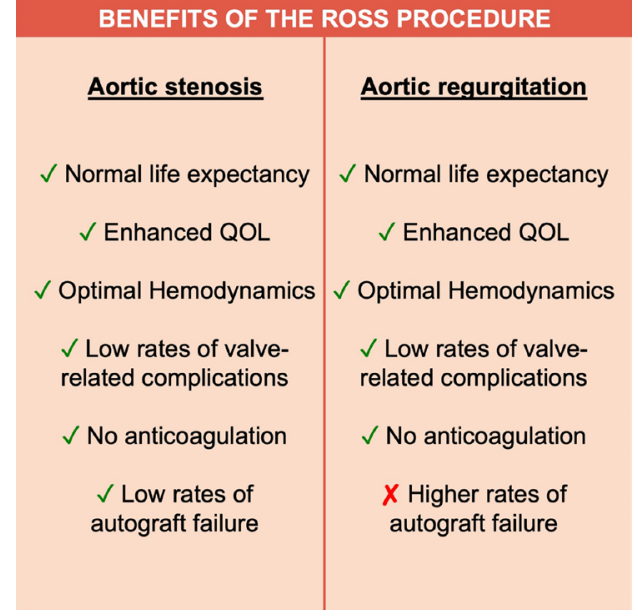

Figure 2 Benefits of the Ross procedure in patients with aortic stenosis and aortic regurgitation.

a gradual understanding of the complex anatomical and physiological considerations involved in its execution (51). As detailed in the previous section, numerous technical modifications and adjunct measures have been proposed to mitigate the risk of late failure, particularly in patients with AR (Table 2). With the introduction of these techniques, it is likely that the results of the operation will continue to improve over time. As such, the current evidence linking pre-operative AR to premature autograft failure-derived from cohorts that antedate the maturation of our surgical techniques-likely represents a "worst-case scenario".

Second, even in the context of this worst-case scenario, it is noteworthy that all large contemporary Ross series have included a significant proportion of patients with pure AR (ranging from $20 \%$ to $50 \%$ ) and yet, rates of reoperation have been very respectable, ranging from $1 \%$ and $2 \%$ per patient-year (15,22,23,25,27,30,52-55).

Third, a large body of evidence suggests that reoperation after the Ross procedure does not amputate long-term survival, and that despite higher rates of reoperation, the survival benefit observed after the Ross procedure is maintained in AR (Figure 2). This is demonstrated by the fact that the majority of contemporary cohort studies with long-term follow-up ( $\geq 15$ years) have reported similar survival between patients who undergo the Ross procedure and the age- and sex-matched general population $(15,23,25,27,30,52-55)$. Furthermore, in a large Ross cohort with a median follow-up of 15 years, Martin et al. reported equivalent long-term survival between patients who required Ross-related reintervention and those who did not (22). While inherently more complex than reoperation after standard AVR, reoperation after the Ross procedure can be carried out with minimal morbidity and mortality in expert centers. For example, in the Toronto experience of 212 patients with a median follow-up of 18 years, there was no mortality at reoperation, nor any severe complication among 33 patients who underwent reoperation after a Ross procedure (30). Moreover, the pulmonary autograft can frequently be salvaged at the time of reoperation, retaining its benefits as a living substitute. This is achieved through isolated valve repair (56) or valve-sparing root replacement (56-58). Using these strategies, several groups have reported rates of successful autograft salvage ranging from $50 \%$ to $90 \%$ (26,59-61). As a result, reoperation should not be seen as an absolute failure in patients who undergo the Ross procedure. These patients are young and are likely to require multiple interventions in their lifetime, irrespective of the choice of initial procedure. Instead, the focus should be on restoring normal life expectancy and quality of life.

Finally, when considering the role of the Ross procedure in young adults with $\mathrm{AR}$, one must always keep in mind the suboptimal results of prosthetic valves-mechanical or biological-in this patient population. In a contemporary large population-based study of patients who underwent surgery in California, mortality at 15 years after bioprosthetic and mechanical AVR in patients aged 45 to 54 years was $31 \%$ and $26 \%$, respectively (11). In addition, there was a high cumulative incidence of prosthesis-related complications, including stroke, bleeding and reoperation (11). Similarly, a recent nationwide study conducted in Sweden demonstrated substantial excess mortality in patients undergoing prosthetic AVR, and showed that the loss in life expectancy increased with younger age (7). Thus, even if the technical refinements described in this article do not entirely mitigate the risk of autograft failure in patients with $\mathrm{AR}$, a tailored Ross procedure may still be the best option.

\section{What about bicuspid aortic valves?}

Aortic regurgitation is frequently encountered in patients with BAVs. It was previously believed that patients with BAVs might be at higher risk of autograft dilatation due to a phenomenon analogous to that of BAV aortopathy $(62,63)$. These theoretical concerns were put to rest by subsequent laboratory experiments demonstrating similar biomechanical properties of pulmonary autografts harvested from patients with bicuspid versus tricuspid aortic valves (64), as well 
as clinical studies showing equivalent outcomes up to 19 years after the Ross procedure, regardless of aortic valve phenotype (65). In fact, in all large contemporary Ross series with long-term follow-up, a significant proportion of patients (ranging from $49 \%$ to $92 \%$ ) have BAV, and yet rates of late aortopathy or dissection have been extremely low $(15,22,23,25,27,30,52-55)$. Thus, the presence of BAV in the absence of inherited aortopathy or connective tissue disease is not considered in and of itself a contraindication to the Ross procedure. It bears mentioning, however, that $\mathrm{BAV}$ is a heterogeneous disorder and that a small subset of patients with BAV have an associated inherited aortopathy. The Ross procedure is contraindicated in these patients, as in all patients with familial aortopathy or connective tissue disease. Finally, some patients with BAV present with a dilated ascending aorta $(>40 \mathrm{~mm})$ without evidence of connective tissue disorder or inherited aortopathy. As previously described, we advocate proactive management of the ascending aorta in these patients with an interposition Dacron graft at the time of the Ross procedure to stabilize the sinotubular junction and ensure that any subsequent increase in ascending aortic diameter is not transmitted to the autograft (Figure 1C).

\section{Future perspectives}

In recent years, significant progress has been made in understanding the mechanisms that lead to autograft dilatation and failure in patients with pre-operative AR. This has allowed for the development of surgical strategies aimed at preventing this late complication. As summarized in this article, external support of the pulmonary autograft is an effective strategy to prevent dilatation. However, this approach raises theoretical concerns related to the restriction of autograft mobility, potentially compromising aortic root hemodynamics and negating some of the longterm benefits of the operation. Future research is required to determine if these theoretical concerns translate into clinically relevant outcomes.

As previously mentioned, in patients who develop pulmonary autograft dilatation after the Ross procedure, most of the increase in diameter is seen early after the operation (33). Thus, if one could provide temporary external support to the autograft during the early remodelling phase, one would allow it to safely adapt to systemic pressures while also ensuring non-restrictive hemodynamics in the long-term and decreasing the risks associated with the use of prosthetic material. The development of fully resorbable bioengineered scaffolds holds great promise in fulfilling this vision. This concept is not new. As early as 1993, Moritz et al. proposed wrapping the pulmonary autograft with an absorbable polyglactin 910 mesh (66). Unfortunately, the long-term outcomes of this approach have not been reported. More recently, advances in the field of biomaterials have led to a resurgence of this concept. Nappi et al. designed a bioengineered semiresorbable scaffold made of a composite of polydioxanone and expanded polytetrafluoroethylene and implanted it in a heterotopic experimental Ross model (67). The scaffold was wrapped around the pulmonary autograft of ten lambs and implanted in their descending aorta. At six months, the scaffold effectively prevented dilatation when compared to the control lambs. The explanted autografts showed no inflammatory changes, and the composite appeared well integrated into the vessel wall. These results are promising, and continued research in this field could potentially provide an optimal solution for patients at risk of autograft dilatation.

Finally, future research should also focus on the medical management of patients undergoing a Ross procedure. Specifically, the identification of biomolecular pathways involved in pulmonary autograft dilatation could uncover potential therapeutic targets.

\section{Conclusions}

The Ross procedure is the best operation to treat AS in young and middle-aged adults (19). However, its role in non-repairable AR remains debated. Several studies have shown that patients with AR are at higher risk of autograft dilatation and failure, leading some to abandon the Ross operation completely in this patient population. Nevertheless, the survival benefit observed in AS, which is secondary to the unique biological and hemodynamic properties of the living autograft, is preserved in patients with AR (Figure 2). As a result, we believe the Ross procedure provides a better option than prosthetic AVR in selected patients with AR in terms of survival, quality of life and hemodynamics. Importantly, we believe that the risk of autograft dilatation can be significantly mitigated with technical refinements and adjunctive measures (Table 2). Using this approach, some groups have already demonstrated excellent long-term durability of the Ross procedure in patients with pure AR (37). As our techniques for the Ross procedure continue to mature, these outcomes will likely continue to improve. As a result, a tailored Ross 
procedure represents an excellent proposition in this patient population.

\section{Acknowledgments}

Funding: None.

\section{Footnote}

Conflicts of Interest: The authors have no conflicts of interest to declare.

Open Access Statement: This is an Open Access article distributed in accordance with the Creative Commons Attribution-NonCommercial-NoDerivs 4.0 International License (CC BY-NC-ND 4.0), which permits the noncommercial replication and distribution of the article with the strict proviso that no changes or edits are made and the original work is properly cited (including links to both the formal publication through the relevant DOI and the license). See: https://creativecommons.org/licenses/by-nc-nd/4.0/.

\section{References}

1. Antoniou A, Harky A, Bashir M, et al. Why I choose to repair and not to replace the aortic valve? Gen Thorac Cardiovasc Surg 2019;67:20-4.

2. Baumgartner H, Falk V, Bax JJ, et al. 2017 ESC/EACTS Guidelines for the management of valvular heart disease. Eur Heart J 2017;38:2739-91.

3. David TE. Aortic valve repair and aortic valve-sparing operations. J Thorac Cardiovasc Surg 2015;149:9-11.

4. Schneider U, Hofmann C, Schöpe J, et al. Long-term Results of Differentiated Anatomic Reconstruction of Bicuspid Aortic Valves. JAMA Cardiol 2020;5:1366-73.

5. Bouhout I, Stevens LM, Mazine A, et al. Long-term outcomes after elective isolated mechanical aortic valve replacement in young adults. J Thorac Cardiovasc Surg 2014;148:1341-1346.e1.

6. Bourguignon T, Bouquiaux-Stablo AL, Candolfi P, et al. Very long-term outcomes of the Carpentier-Edwards Perimount valve in aortic position. Ann Thorac Surg 2015;99:831-7.

7. Glaser N, Persson M, Jackson V, et al. Loss in Life Expectancy After Surgical Aortic Valve Replacement: SWEDEHEART Study. J Am Coll Cardiol 2019;74:26-33.

8. Kvidal P, Bergström R, Hörte LG, et al. Observed and relative survival after aortic valve replacement. J Am Coll
Cardiol 2000;35:747-56.

9. Mihaljevic T, Nowicki ER, Rajeswaran J, et al. Survival after valve replacement for aortic stenosis: implications for decision making. J Thorac Cardiovasc Surg 2008;135:1270-8; discussion 1278-9.

10. Glaser N, Jackson V, Holzmann MJ, et al. Aortic valve replacement with mechanical vs. biological prostheses in patients aged 50-69 years. Eur Heart J 2016;37:2658-67.

11. Goldstone AB, Chiu P, Baiocchi M, et al. Mechanical or Biologic Prostheses for Aortic-Valve and Mitral-Valve Replacement. N Engl J Med 2017;377:1847-57.

12. Isaacs AJ, Shuhaiber J, Salemi A, et al. National trends in utilization and in-hospital outcomes of mechanical versus bioprosthetic aortic valve replacements. J Thorac Cardiovasc Surg 2015;149:1262-9.e3.

13. Carabello BA. Valve-in-Valve TAVR: Insights Into the Pathophysiology of Aortic Stenosis. J Am Coll Cardiol 2017;69:2263-5.

14. Ross DN. Replacement of aortic and mitral valves with a pulmonary autograft. Lancet 1967;2:956-8.

15. El-Hamamsy I, Eryigit Z, Stevens LM, et al. Longterm outcomes after autograft versus homograft aortic root replacement in adults with aortic valve disease: a randomised controlled trial. Lancet 2010;376:524-31.

16. Mazine A, David TE, Rao V, et al. Long-Term Outcomes of the Ross Procedure Versus Mechanical Aortic Valve Replacement: Propensity-Matched Cohort Study. Circulation 2016;134:576-85.

17. Sharabiani MT, Dorobantu DM, Mahani AS, et al. Aortic Valve Replacement and the Ross Operation in Children and Young Adults. J Am Coll Cardiol 2016;67:2858-70.

18. Buratto E, Shi WY, Wynne R, et al. Improved Survival After the Ross Procedure Compared With Mechanical Aortic Valve Replacement. J Am Coll Cardiol 2018;71:1337-44.

19. Ouzounian M, Mazine A, David TE, et al. The Ross procedure is the best operation to treat aortic stenosis in young and middle-aged adults. J Thorac Cardiovasc Surg 2017;154:778-82.

20. David TE, Woo A, Armstrong S, et al. When is the Ross operation a good option to treat aortic valve disease? J Thorac Cardiovasc Surg 2010;139:68-73; discussion 73-5.

21. Charitos EI, Takkenberg JJ, Hanke T, et al. Reoperations on the pulmonary autograft and pulmonary homograft after the Ross procedure: An update on the German Dutch Ross Registry. J Thorac Cardiovasc Surg 2012;144:813-21; discussion 821-3.

22. Martin E, Mohammadi S, Jacques F, et al. Clinical 
Outcomes Following the Ross Procedure in Adults: A 25-Year Longitudinal Study. J Am Coll Cardiol 2017;70:1890-9.

23. Skillington PD, Mokhles MM, Takkenberg JJ, et al. The Ross procedure using autologous support of the pulmonary autograft: techniques and late results. J Thorac Cardiovasc Surg 2015;149:S46-52.

24. Svensson LG, Adams DH, Bonow RO, et al. Aortic valve and ascending aorta guidelines for management and quality measures. Ann Thorac Surg 2013;95:S1-66.

25. Weimar T, Charitos EI, Liebrich M, et al. Quo vadis pulmonary autograft--the ross procedure in its second decade: a single-center experience in 645 patients. Ann Thorac Surg 2014;97:167-74.

26. Mastrobuoni S, de Kerchove L, Solari S, et al. The Ross procedure in young adults: over 20 years of experience in our Institution. Eur J Cardiothorac Surg 2016;49:507-12; discussion 512-3.

27. da Costa FD, Takkenberg JJ, Fornazari D, et al. Longterm results of the Ross operation: an 18-year single institutional experience. Eur J Cardiothorac Surg 2014;46:415-22; discussion 422.

28. Ryan WH, Prince SL, Culica D, et al. The Ross procedure performed for aortic insufficiency is associated with increased autograft reoperation. Ann Thorac Surg 2011;91:64-9; discussion 69-70.

29. David TE, David C, Woo A, et al. The Ross procedure: outcomes at 20 years. J Thorac Cardiovasc Surg 2014;147:85-93.

30. David TE, Ouzounian M, David CM, et al. Late results of the Ross procedure. J Thorac Cardiovasc Surg 2019;157:201-8.

31. David TE, Omran A, Webb G, et al. Geometric mismatch of the aortic and pulmonary roots causes aortic insufficiency after the Ross procedure. J Thorac Cardiovasc Surg 1996;112:1231-7; discussion 1237-9.

32. Lenoir M, Emmott A, Bouhout I, et al. Autograft remodeling after the Ross procedure by cardiovascular magnetic resonance imaging: Aortic stenosis versus insufficiency. J Thorac Cardiovasc Surg 2020. [Epub ahead of print]. doi: 10.1016/j.jtcvs.2020.03.185.

33. Hokken RB, Takkenberg JJ, van Herwerden LA, et al. Excessive pulmonary autograft dilatation causes important aortic regurgitation. Heart 2003;89:933-4.

34. Navarra E, El Khoury G, Glineur D, et al. Effect of annulus dimension and annuloplasty on bicuspid aortic valve repair. Eur J Cardiothorac Surg 2013;44:316-22; discussion 322-3.
35. Carrel T, Kadner A, et al. Long-Term Clinical and Imaging Follow-Up After Reinforced Pulmonary Autograft Ross Procedure. Semin Thorac Cardiovasc Surg Pediatr Card Surg Annu 2016;19:59-62.

36. Bouhout I, Ghoneim A, Tousch M, et al. Impact of a tailored surgical approach on autograft root dimensions in patients undergoing the Ross procedure for aortic regurgitation†. Eur J Cardiothorac Surg 2019;56:959-67.

37. Mazine A, Ghoneim A, El-Hamamsy I, et al. The Ross Procedure: How I Teach It. Ann Thorac Surg 2018;105:1294-8.

38. Poh CL, Buratto E, Larobina M, et al. The Ross procedure in adults presenting with bicuspid aortic valve and pure aortic regurgitation: $85 \%$ freedom from reoperation at 20 years. Eur J Cardiothorac Surg 2018;54:420-6.

39. Pacifico AD, Kirklin JK, McGiffin DC, et al. The Ross operation--early echocardiographic comparison of different operative techniques. J Heart Valve Dis 1994;3:365-70.

40. Carrel T, Schwerzmann M, Eckstein F, et al. Preliminary results following reinforcement of the pulmonary autograft to prevent dilatation after the Ross procedure. J Thorac Cardiovasc Surg 2008;136:472-5.

41. Juthier F, Banfi C, Vincentelli A, et al. Modified Ross operation with reinforcement of the pulmonary autograft: Six-year results. J Thorac Cardiovasc Surg 2010;139:1420-3.

42. Koul B, Al-Rashidi F, Bhat M, et al. A modified Ross operation to prevent pulmonary autograft dilatation. Eur J Cardiothorac Surg 2007;31:127-8.

43. Ungerleider RM, Ootaki Y, Shen I, et al. Modified Ross procedure to prevent autograft dilatation. Ann Thorac Surg 2010;90:1035-7; discussion 1037.

44. Vanderveken E, Vastmans J, Verbelen T, et al. Reinforcing the pulmonary artery autograft in the aortic position with a textile mesh: a histological evaluation. Interact Cardiovasc Thorac Surg 2018;27:566-73.

45. Fries R, Graeter T, Aicher D, et al. In vitro comparison of aortic valve movement after valve-preserving aortic replacement. J Thorac Cardiovasc Surg 2006;132:32-7.

46. Furukawa K, Ohteki H, Cao ZL, et al. Evaluation of native valve-sparing aortic root reconstruction with direct imaging--reimplantation or remodeling? Ann Thorac Surg 2004;77:1636-41.

47. Nappi F, Carotenuto AR, Cutolo A, et al. Compliance mismatch and compressive wall stresses drive anomalous remodelling of pulmonary trunks reinforced with Dacron grafts. J Mech Behav Biomed Mater 2016;63:287-302. 
48. Kollar AC, Lick SD, Palacio DM, et al. Ross procedure with a composite autograft using stretch Gore-Tex material. Ann Thorac Surg 2009;88:e34-6.

49. Ootaki Y, Walsh MJ, Shen I, et al. Ross procedure for patient with Marfan syndrome. Ann Thorac Surg 2014;97:2186-8.

50. Basmadjian L, Basmadjian AJ, Stevens LM, et al. Early results of extra-aortic annuloplasty ring implantation on aortic annular dimensions. J Thorac Cardiovasc Surg 2016;151:1280-5.e1.

51. Yacoub MH. The Ross operation--an evolutionary tale. Asian Cardiovasc Thorac Ann 2006;14:1-2.

52. Andreas M, Seebacher G, Reida E, et al. A single-center experience with the ross procedure over 20 years. Ann Thorac Surg 2014;97:182-8.

53. Mazine A, El-Hamamsy I, Verma S, et al. Ross Procedure in Adults for Cardiologists and Cardiac Surgeons: JACC Stateof-the-Art Review. J Am Coll Cardiol 2018;72:2761-77.

54. Sievers HH, Stierle U, Charitos EI, et al. A multicentre evaluation of the autograft procedure for young patients undergoing aortic valve replacement: update on the German Ross Registry†. Eur J Cardiothorac Surg 2016;49:212-8.

55. Sievers HH, Stierle U, Petersen M, et al. Valve performance classification in 630 subcoronary Ross patients over 22 years. J Thorac Cardiovasc Surg 2018;156:79-86.e2.

56. Liebrich M, Weimar T, Tzanavaros I, et al. The David procedure for salvage of a failing autograft after the Ross operation. Ann Thorac Surg 2014;98:2046-52.

57. Luciani GB, Viscardi F, Pilati M, et al. The Ross-Yacoub procedure for aneurysmal autograft roots: a strategy to preserve autologous pulmonary valves. J Thorac Cardiovasc Surg 2010;139:536-42.

58. Mookhoek A, de Kerchove L, El Khoury G, et al.

Cite this article as: Mazine A, El-Hamamsy I. The Ross procedure is an excellent operation in non-repairable aortic regurgitation: insights and techniques. Ann Cardiothorac Surg 2021;10(4):463-475. doi: 10.21037/acs-2021-rp-25
European multicenter experience with valve-sparing reoperations after the Ross procedure. J Thorac Cardiovasc Surg 2015;150:1132-7.

59. Luciani GB, Lucchese G, De Rita F, et al. Reparative surgery of the pulmonary autograft: experience with Ross reoperations. Eur J Cardiothorac Surg 2012;41:1309-14; discussion 1314-5.

60. Hussain ST, Majdalany DS, Dunn A, et al. Early and mid-term results of autograft rescue by Ross reversal: A one-valve disease need not become a two-valve disease. J Thorac Cardiovasc Surg 2018;155:562-72.

61. Kumar SR, Bansal N, Wells WJ, et al. Outcomes of Reintervention on the Autograft After Ross Procedure. Ann Thorac Surg 2016;102:1517-21.

62. Fedak PW, de Sa MP, Verma S, et al. Vascular matrix remodeling in patients with bicuspid aortic valve malformations: implications for aortic dilatation. J Thorac Cardiovasc Surg 2003;126:797-806.

63. Verma S, Siu SC, et al. Aortic dilatation in patients with bicuspid aortic valve. N Engl J Med 2014;370:1920-9.

64. Dionne PO, Wener E, Emmott A, et al. The Ross procedure: biomechanical properties of the pulmonary artery according to aortic valve phenotype. Interact Cardiovasc Thorac Surg 2016;23:371-6.

65. Hanke T, Charitos EI, Stierle U, et al. The Ross operation - a feasible and safe option in the setting of a bicuspid aortic valve? Eur J Cardiothorac Surg 2010;38:333-9.

66. Mortiz A, Domanig E, Marx M, et al. Pulmonary autograft valve replacement in the dilated and asymmetric aortic root. Eur J Cardiothorac Surg 1993;7:405-8.

67. Nappi F, Spadaccio C, Fraldi M, et al. A composite semiresorbable armoured scaffold stabilizes pulmonary autograft after the Ross operation: Mr Ross's dream fulfilled. J Thorac Cardiovasc Surg 2016;151:155-64.e1. 